\title{
Anti-CD45 Monoclonal Antibody AHN-12
}

National Cancer Institute

\section{Source}

National Cancer Institute. Anti-CD45 Monoclonal Antibody AHN-12. NCI Thesaurus.

Code C74009.

A high affinity IgG1 monoclonal antibody with potential immunotherapeutic activity. AntiCD45 monoclonal antibody AHN-12 recognizes CD45, a transmembrane protein tyrosine phosphatase that is expressed on the surface of normal and malignant hematopoietic cells. 